\title{
EGGSHELL STRENGTH IN MOLTED AND NON-MOLTED LAYERS UNDER SUMMER HEAT STRESS PERIOD
}

\author{
Dragoslav Kocevski ${ }^{1}$, Gjoko Bunevski ${ }^{1}$, Vladimir Djabirski ${ }^{1}$, Vlado Vukovikj ${ }^{1}$, Kocho Porchu ${ }^{1}$, \\ Nedeljka Nikolova ${ }^{2}$, Goran Tashev ${ }^{1}$, Danail Shutevski ${ }^{1}$ \\ ${ }^{1}$ Institute of Animal Biotechnology, Faculty of Agricultural Science and Food, \\ University "Ss Cyril and Methodius" in Skopje, Republic of Macedonia \\ ${ }^{2}$ Institute of Animal Science, "Ss Cyril and Methodius" University in Skopje, Republic of Macedonia \\ Dragoslav.Kocevski@yahoo.com
}

\begin{abstract}
An analysis was performed of eggs' quality parameters in the period of the high-temperature summer (July, August) heat-stress period (egg weight, yolk color, Hough units and eggshell strength) in two flocks of commercial laying hens at advanced age. Each flock consisted of ISA Brown (IB) and DeKalb White (DK) mixed-genetic layers kept in two separate hen-houses equipped with battery cages. The first flock (F1-7334 DK and $8233 \mathrm{IB}$ ) was at the $72 \mathrm{nd}$ week of age at the start of the monitored period, and the second one (F2 - $7833 \mathrm{DK}$ and $8815 \mathrm{IB})$ at the $92 \mathrm{nd}$ week of age after being molted at the 70th week of age. In-house environment ventilation as well as hens' feeding (following technical recommendations) were approximately same for both hen-houses throughout the laying cycle. Eggshell quality of 240 egg samples (30 eggs/month/breed F1 or F2) was analyzed in the laboratory for testing egg quality using Eggshell Gauge (Robotmation Co. Ltd., Tokyo, Japan), a computerized equipment that gives unbiased values. Both genotypes yielded high egg production close to the technological level. Molted ISA Brown layers produce eggs that on average have $400 \mathrm{~g} / \mathrm{cm}^{2}$ stronger shells than the eggs of non-molted layers (mean values of 4,027.63 vs. $3,569.83 \mathrm{~g} / \mathrm{cm}^{2}$ in July and $3,748.67$ vs. $3,334.70 \mathrm{~g} / \mathrm{cm}^{2}$ in August). Same tendency was registered in DeKalb White layers' flock (mean values of $3,743.83$ vs. $3,535.67 \mathrm{~g} / \mathrm{cm}^{2}$ in July and $3,400.23 \mathrm{vs.} 3,104.53 \mathrm{~g} / \mathrm{cm}^{2}$ in August). The data obtained confirm that heat stress negatively influences shell strength and that molting improves layers' shell strength production capacity and helps mitigation of heat-stress negative effects.
\end{abstract}

Key words: eggshell strength; heat stress; molting; layers

\section{ЦВРСТИНА НА ЛУШПАТА НА ЈАЈЦАТА КАЈ МИТАРЕНИ И НЕМИТАРЕНИ НЕСИЛКИ ВО УСЛОВИ НА ТОПЛОТЕН СТРЕС ВО ЛЕТНИОТ ПЕРИОД}

Со опитот се реализираа истражувања на параметрите за квалитет на јајцата (тежина на јајцата, боја на жолчката, Хофови единици и цврстина на лушпата) во периодот со високи летни температури (јули, август), т.е. периодот на топлотен стрес кај две јата комерцијални несилки во напредната возраст. Секое јато се состоеше од различни генотипови на несилки, и тоа од ISA Brown (IB) и DeKalb White (DK), сместени во два одделни објекта опремени со батериски кафези. Едното јато (F1 - 7334 DK и 8233 IB) беше во 72 -ата недела на возраст на почетокот на мониторингот, а второто (F2 - 7833 DK и 8815 IB) во 92-ата недела на возраст откако беше митарено на 70-неделна возраст. Внатрешната амбиентална вентилација, како и исхраната (по техничка препорака) беше приближно иста во двата објекта во текот на циклусот на несење. Во лабораторијата за испитување на квалитет на јајца беа испитани 240 примероци на јајца (30 јајца / месец / paca / F1 или F2) со помош на инструмент за мерење на цврстината на лушпата кај јајцата (Robotmation Co. Ltd., Токио, Јапонија), компјутеризирана опрема која дава непристрасни вредности. Двата генотипа дадоа високо производство на јајца блиску до технолошките можности. Митарените несилки од ISA Brown произведоа јајца кои во просек имаат за $400 \mathrm{~g} / \mathrm{cm}^{2}$ поцврсти лушпи од јајцата добиени од немитарените несилки (средни вредности 4027,63 наспроти $3569,83 \mathrm{~g} / \mathrm{cm}^{2}$ во јули и 3748,67 наспроти $3334,70 \mathrm{~g} / \mathrm{cm}^{2}$ во август). Истата тенденција беше забележена кај белите несилки DeKalb (средни вредности од 3743,83 наспроти $3535,67 \mathrm{~g} / \mathrm{cm}^{2}$ во јули и 3400,23 наспроти 3104,53 $\mathrm{g} / \mathrm{cm}^{2}$ во август). Податоците потврдуваат дека топлотниот стрес негативно влијае врз цврстината на јајцевата лушпа и дека митарењето кај несилките го подобрува производствениот капацитет на јајца со цврста лушпа и помага во ублажување на негативните ефекти од топлотниот стрес.

Клучни зборови: цврстина на лушпата на јајцата; топлотен стрес; митарење; несилки 


\section{INTRODUCTION}

One of the crucial problems facing the world egg industry in summer months is heat stress of layers causing lower feed intake, decreased body weight, increased feed conversion and lower production (Mashaly et al., 2004). Heat stress cause decreased egg quality, lower eggshell strength and elevated brakes and cracks on the eggshell during the egg manipulations in the farmhouse, at the grading and packing centers, distribution and in the markets shelves (Lin et al., 2004; Nikolova et al. 2008). Additionally, according Ebeid et al. (2012), heat stress induces lower egg mass $(-3,24 \%)$, eggshell thickness $(-1,2 \%)$, eggshell weight $(-9,93 \%)$ and eggshell percentage out of the whole egg $(-0,66 \%)$. Layers submitted to heat stress express lower egg production and egg mass (Njoya and Picard, 1994; Mashaly et al., 2004) as compared to those maintained in thermal comfort. Star et al. (2009) reported a reduction of $31.6 \%$ in feed conversion, $36.4 \%$ in egg production, and $3.41 \%$ in egg weight in laying hens subjected to heat stress. In another study (Lin et al., 2004), heat stress caused decreased production performance, as well as reduced eggshell thickness, and increased egg breakage.

Molting is a process regulated by thyroid gland hormones, leading the birds to rest from egg production and regenerating the reproductive organs at the onset of the new production cycle (Gjorgovska and Filev, 2010), increasing the nutrients depot in the birds, seizes the egg production and generate feather replacements (Brake, 1993). Induced molting in commercial hens is practiced in many parts of the world in the last few decades aiming to improve performances, egg quality parameters and profitability, in elderly hens. Eggshell strength is rapidly declining by the end of the first production cycle because of the high daily egg mass output (higher egg size). This problem could be partially overcome of induced molting, that is management techniques consist of several sets of practices leading to stress situation for the laying hens and resulting in seize of egg production (Roland and Brake, 1982).

There are several different methods of induced molting in layers. One of the most practical ones is limitation of the feed intakes. Eggs produced during the second production cycle (after molting) usually have higher egg mass compared to the eggs produced in the first production cycle, eggshell quality is improved in comparison with the eggshell quality at the end of the first cycle of production, egg production intensity could come to $92-94 \%$ of the egg in- tensity in the first production cycle but the feed conversion rate (due to the lower egg production intensity) is 10\% higher (Gjorgovska et al., 2012).

The goal of this trial was to investigate the influence of high summer temperatures and heat stress on the egg quality or more precisely on the eggshell strength in molted and un-molted layers at advanced age.

\section{MATERIAL AND METHODS}

Data for the eggshell strength of the eggs produced by two mixed flocks (white and brown) of layers (ISA Brown - IB, and DeKalb White - DK) housed in two separate henp-houses equipped with battery cages were analyzed. The first flock (F1 7334 DK and 8233 IB) was on $72^{\text {nd }}$ week of age at the beginning of the monitored period. The second layers flock (F2 - 7833 DK and 8815 IB) was on $92^{\text {nd }}$ week of age at the beginning of the monitoring period, after being molted on the age of $70^{\text {th }}$ weeks. In-house environmental ambient and feeding regimes (following technical recommendations for nutrient requirements of the genotypes) were approximately same for both flocks during the production cycles. Total of 240 samples of eggs produced by molted and non-molted layers in the months July and August (30 eggs/month/genotype/F1 or F2) were analyzed. Eggshell strength was analyzed in the laboratory of control of the marketing quality of eggs at the Institute of Animal Biotechnology on the Faculty of Agricultural Science and Food, using computerized equipment (Eggshell Force Gauge, Robotmation Co. Ltd., Tokyo, Japan).

\section{RESULTS AND DISCUSSION}

Data from the analyses of the eggshell strength in molted and non-molted layers of ISA Brown and Dekalb White genetic provenience, collected during the hottest period of the summer (months July and August) are presented in the Table 1. Eggshell strength is expressed in $\mathrm{g} / \mathrm{cm}^{2}$.

Eggshell strength in un-molted layers in July had approximately the same value in both genotypes. ISA Brown had no significantly higher value $\left(3569.83 \mathrm{~g} / \mathrm{cm}^{2}\right)$ compared to Dekalb White $\left(3535.67 \mathrm{~g} / \mathrm{cm}^{2}\right)$. Average value for both genotypes was $3552.75 \mathrm{~g} / \mathrm{cm}^{2}$. 
Table 1

Eggshell strength in eggs of molted and non-molted layers of both genotypes produced in July and August $\left(\mathrm{g} / \mathrm{cm}^{2}\right)$

\begin{tabular}{|c|c|c|c|}
\hline & ISA Brown & Dekalb White & Average value for both genotypes \\
\hline \multicolumn{4}{|c|}{ UN-MOLTED LAYERS } \\
\hline July & 3569.83 & 3535.67 & 3552.75 \\
\hline August & 3334.70 & 3104.53 & 3219.62 \\
\hline \multicolumn{3}{|c|}{ Average values for both months and both genotypes } & 3386.18 \\
\hline \multicolumn{4}{|c|}{ MOLTED LAYERS } \\
\hline July & 4027.63 & 3743.83 & 3885.73 \\
\hline August & 3748.67 & 3400.23 & 3574.45 \\
\hline \multicolumn{3}{|c|}{ Average values for both months and both genotypcs } & 3730.09 \\
\hline
\end{tabular}

Molted layers values for eggshell strength in July expressed different values compared to the unmolted ones (Graph 1). Estimated average values of the samples measured in ISA Brown were 4027.63 $\mathrm{g} / \mathrm{cm}^{2}$, and $3743.83 \mathrm{~g} / \mathrm{cm}^{2}$ in Dekalb White. These average values are higher than the values in unmolted layers for July. ISA Brown expressed higher average values than Dekalb White. Average value for both genotypes for July is $3885.73 \mathrm{~g} / \mathrm{cm}^{2}$ and is $300 \mathrm{~g} / \mathrm{cm}^{2}$ higher compared to the average value of un-molted layers.

Average values for eggshell strength in August were higher in ISA Brown $\left(3334.70 \mathrm{~g} / \mathrm{cm}^{2}\right)$ compared to Dekalb White genotype $\left(3104.53 \mathrm{~g} / \mathrm{cm}^{2}\right)$. Average value for both genotypes was 3219.62 $\mathrm{g} / \mathrm{cm}^{2}$.

Molted layers had also higher average values for eggshell strength in August. Average value for eggshell strength In ISA Brown layers was 3748.67 $\mathrm{g} / \mathrm{cm}^{2}$, and in Dekalb White $3400.23 \mathrm{~g} / \mathrm{cm}^{2}$ compared to $3334.70 \mathrm{~g} / \mathrm{cm}^{2}$ and 3104.53 in ISA Brown and Dekalb White un-molted layers, respectively. ISA Brown again expressed higher average values than Dekalb White. Average eggshell strength value for both hybrids in August is $3574.45 \mathrm{~g} / \mathrm{cm}^{2}$ and is higher compared to un-molted $\left(3219.62 \mathrm{~g} / \mathrm{cm}^{2}\right)$.

The difference in the average value for shell strength in August is visible on the Graph 2 and it could be noticed that molted ISA Brown layers expressed the highest average values and un-molted layers of Dekalb White genotype showed the weakest average value for eggshell strength.

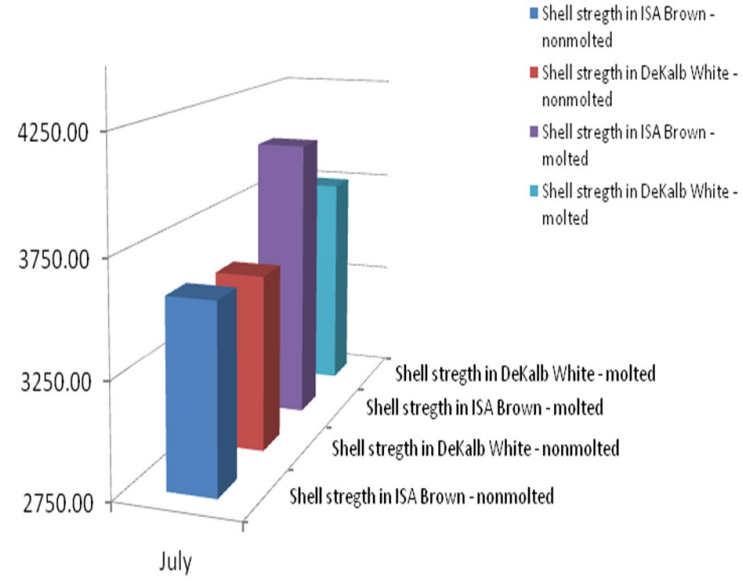

Graph 1. Average values of eggshell strength in molted and un-molted layers of both genotypes in July

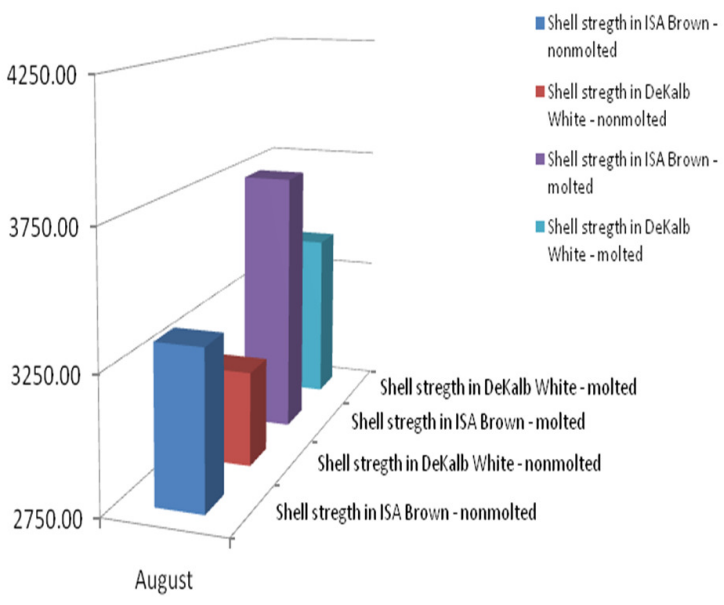

Graph 2. Average values of eggshell strength in molted and un-molted layers of both genotypes in August 
The management practice of "forced" or "induced" molting has shown to improve eggshell quality in all ageing flock. Following the molt, egg specific gravity, eggshell weight, eggshell thickness and percentage eggshell were either the same as they had been prior to the molt, or had improved, for all strains. Eggshell breaking strength improved in all strains as the result of the induced molting (The Poultry Site, 2008).

We noted that there is a difference between the two genotypes in favorite of ISA Brown, which produce eggs with stronger eggshell strength (in line with the genotypes standards declared by the breeding companies). Other finding was that there is difference in the average value for eggshell strength in July and August. Finally, there is noticeable advantage in the eggshell strength in molted compared to un-molted layers. Sgavioli et al. (2011) reported similar facts, stating that increased temperatures reduced egg mass, however, the evaluated forcedmolting methods and temperatures to which the birds were submitted did not influence the other performance parameters.

Generally, eggs produced in July and August from ISA Brown (genotype that produces brown colored eggs - eggs with brown shell) had stronger eggshell compared to Dekalb White (genotype that produces eggs with white shell) that is in-line with the findings of Ledvinka et al. (2000) that brown egg layers produce higher shell weight in comparison with some other hybrids of white color.

Graph 3 presents comparison of the average values for eggshell strength in molted and unmolted layers in both genotypes, regardless the month of production as a fix factor.

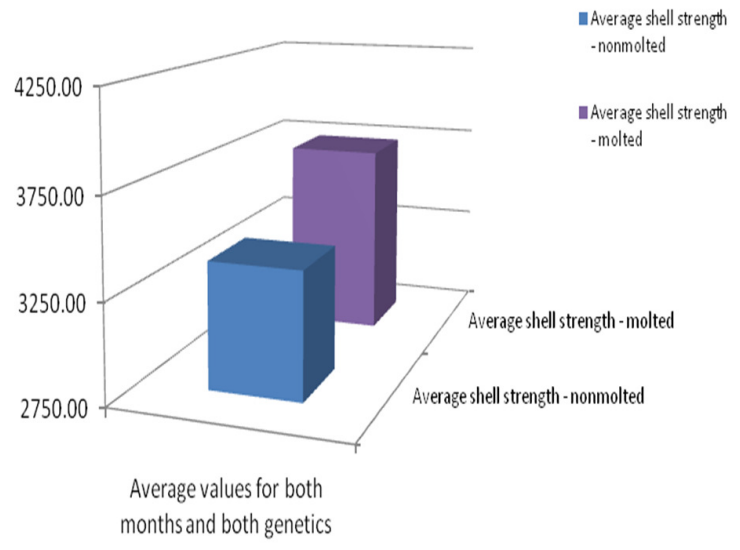

Graph 3. Comparative average values for eggshell strength of molted and un-molted layers regardless the genotype $\left(\mathrm{g} / \mathrm{cm}^{2}\right)$
It is noticeable that average value for eggshell strength in molted layers $\left(3730.09 \mathrm{~g} / \mathrm{cm}^{2}\right)$ is aproximately $400 \mathrm{~g} / \mathrm{cm}^{2}$ higher compared to average value for eggshell strength in un-molted layers (3386.18 $\left.\mathrm{g} / \mathrm{cm}^{2}\right)$. This is in line with the Gjorgovska's et al. (2012) conclusions. They also concluded that during the second egg laying cycle egg weight and eggshell characteristics are increasing rapidly.

\section{CONCLUSIONS}

Molted ISA Brown layers produce eggs that on average have $400 \mathrm{~g} / \mathrm{cm}^{2}$ stronger eggshell than eggs of un-molted layers (mean values of 4027.63 vs. $3569.83 \mathrm{~g} / \mathrm{cm}^{2}$ in July and 3748.67 vs. 3334.70 $\mathrm{g} / \mathrm{cm}^{2}$ in August).

Same tendency was monitored in DeKalb White flock of layers (mean values of 3743.83 vs. $3535.67 \mathrm{~g} / \mathrm{cm}^{2}$ in July and 3400.23 vs. 3104.53 $\mathrm{g} / \mathrm{cm}^{2}$ in August).

Data confirm that heat stresses negatively influence eggshell on strength and that molting improve eggshell strength production capacity of layers and helps mitigation of heat stress negative effects.

\section{REFERENCES}

[1] Brake J.: Recents advances in induced molting. Poultry Science, 72, 929-931 (1993).

[2] Ebeid T. A., Suzuki T., Sugiyama T.: High temperature influences eggshell quality and calbindin - D28k localization of eggshell gland and all intestinal segments of laying hens. Poult. Sci., 91, 2282-2287 (2012).

[3] Gjorgovska N., Filev K.: Morfological and productive transformation of molted hens, Lucrări Ştiinţifice - Seria Agronomie, Vol. 53 (1), 18-21 (2010).

[4] Gjorgovska N., Filev K., Levkov V., Kostadinov T., Jusufi E.: Egg production during the artificial moulting and a new laying cycle of aged hens. Archiva Zootechnica, 15, 1, 5360 (2012).

[5] Gjorgovska N., Filev K., Levkov V., Nikolova N., Kostadinov T.: Eggshell quality of aged hens during the rejuvenation. Lucrări Ştiinţifice - Seria Zootehnie, Vol. 58, 277 280 (2012).

[6] Ledvinka Z., Tůmova E., Arent E., Holoubek J., Klesalová L.: Eggshell quality in some white egg and brown-egg cross combinations of dominant hens. Czech. J. Anim. Sci., 45, 285-288 (2000).

[7] Lin H., Mertens K., Kemps B., Govaerts T., De Ketelaere B., De Baerdemaeker J., Decuypere E., Buyse J.: New approach of testing the effect of heat stress on eggshell quality: Mechanical and material properties of eggshell and membrane. Br. Poult. Sci., 45, 476-482 (2004). 
[8] Mashaly M. M., Hendricks G. L. III., Kalama M. A., Gehad A. E., Abbas A. O., Patterson P. H. (2004). Effect of heat stress on production parameters and immune responses of commercial laying hens. Poult. Sci., 83, 889-894 (2004).

[9] Nikolova N., Pavlovski Z., Milosevic N., Wahner M.: Influence of heat stress and age on the percentage of calcium carbonate in eggshell and the percentage of broken and cracked eggs. Arch. Tierz., Dummerstorf, 51, 4, 389-396 (2008).

[10] Njoya J, Picard M.: Climatic adaptation of laying hens. Tropical Animal Health Production. 26, 180-186 (1994).

[11] Roland D. A., Brake J. H.: Influence of premolt production on postmolt performance with explanation for improvement in egg production due to force molting. Poultry Science, 61 (12), 2473-2481 (1982).
[12] Sgavioli S., Filardi R. da S., Praes MFFM, Assuena V., Pileggi J., Andrade P. de C., Boleli I. C., Junqueira O. M.: Performance of layers submitted to different forced-molting methods and different temperatures. Rev. Bras. Cienc. Avic., Vol. 13, No. 3 (2011).

[13] Star L., Juul-Madsen H. R., Decuypere E., Nieuwland M. G., De Vries Reilingh G., Van den Brand H., Kemp B., Parmentier H. K.: Effect of early life thermal conditioning and immune challenge on thermotolerance and humoral immune competence in adult laying hens. Poult. Sci., 88, 2253-2261 (2009).

[14] The Poultry Site (2008): Factors Influencing Shell Quality, http://www.thepoultrysite.com/articles/1003/factors-influencing-shell-quality/ 
